\title{
Significant Activities Of The Centre
}

\section{Centre of Excellence for Women's Studies:}

Founded in 1989 by the Ministry of Women Development, Youth Affairs and Special Education, the Centre is an outcome of the continuous realization of the Government of Pakistan to integrate women's development and women's rights in its national policies. The Centre is first in Pakistan to offer M.A degree in Women's Studies from 1996 and onwards. In 2007 the Centre has started B.S. (4 years) programme in Women's Studies. It is also the first institution to offer M.Phil/Ph.D. degree in Women's Studies from the year 2002.

\section{Publications of the Centre}

- Directory of Experts \& Research Persons in Women and Development in Pakistan, 1993.

- Challenge for Change: Literacy for the Girl of Today, the Woman of Tomorrow, 1995.

- Trafficking of women and children in South Asia and within Pakistan- 2001.

- Home workers: The Silent Work Force- 2002

- Beggar Girls of Karachi: A Survey, HEC \& CEWS, September 2004.

\section{Studies undertaken with the grant given by Higher Education Commission (HEC)}

- “Women's Experience of Religious and Social Traditions: Gender, Religious Authority and Devotional Islam in Pakistan”, 2007.

- "The Role of Women Councillors in Local Government system and its impact on the political status of women in Pakistan", 2007.

- “GIRL CHILD: Issues and Challenges”, 2007.

\section{Seminars}

- The Centre celebrated Women's Day, $8^{\text {th }}$ March, 2006 by organizing one day seminar on "Role of Women Councilors in Local Bodies Govt. System (Muqami hukumat may khawateen councillors ka kirdar)", funded by HEC and organized in collaboration with the Anjuman-e-Taraqqi-e-Niswan.

- The Centre celebrated Women's Day, $8^{\text {th }}$ March, 2007 by organizing a one day seminar on "Economic Development of Self Employed Women: Role of Town Nazims (Khud Ikhtiari Khawateen Ki Muashi Taraqqi:Town Nazmeen Ka Kirdr)" funded by HEC and organized in collaboration with the Anjuman-e-Taraqqi-eNiswan. 


\section{Strengthening \& Development Works}

- Computer lab has been established for research work with funds provided by Higher Education Commission (HEC).

- Recently Ministry of Women \& Development Govt. of Pakistan funded for upgrading the library. Further more the Centre has a separate corner for displaying these books to pay tribute to Madr-e-Millat "Fatmia Jinnah".

\section{On-going Works}

- Centre is also preparing its directory of passed out students consisting information of organizations in which they are working and their field of expertise.

- Working on publishing a magazine "Panghat".

- Recently Ministry of Women \& Development Govt. of Sindh allocated grant of Rs.500,000/- for research work, printing of journal, purchase of books, training workshops and office equipment to strengthen and develop the Centre.

- Honorable Minister Mrs. Nadira Panjwani donated Rs.500,000/- from her personal funds for construction of a room for seminars and workshops. 


\section{Collection From News Papers}

\section{Child Labour}

- No latest data on child labor in Pakistan has been compiled, the last survey in 1996 figured out 3.3 million child laborers in Pakistan, out of which 2.4 million (73\%) were boys and 0.9 million (27\%) were girls. (Dawn, Tuesday, June 12,2007).

\section{Child Abuse}

- An Islamabad based Civil society organization 'Sahil' working against child sex abuse, reported that 815 cases of child sexual abuse were reported during April - June to 500 during Jan. - March - an increase of 315 cases in just 90 days. Among abused children the numbers of girls was more then double of the boys. In all 1,315 children were reportedly abused of them the number of girls was $891(68 \%)$ against 424 boys (32\%). (Dawn, Friday, July 20, 2007).

\section{Police Women}

- Police women being sidelined despite gender policy notified by the Sindh police early year, under which women are to be encouraged to join the police force and police women are to be posted to field assignments. Despite a severe shortage of staff, there has been no major induction of female recruits. Against the 1,051 posts sanctioned for women in 2007 there are only 214 police women in Karachi- 07 DSPs, 20 inspectors, 23 sub-inspectors, 40 ASIs, 10 head constables and 114 constables. By contrast police men number at about 29,000 in the city. (Dawn, Friday, Oct. 12,2007).

\section{International Position}

- Kashmala Tariq, leading MNA was elected the new chairperson of Common Wealth Women Parliamentarian's (CWP) group, defeating her Canadian rival by 41 votes to 32. (Dawn, Tuesday, Sept.25,2007).

\section{Female Illiteracy}

- According to a recently released report by ILO, the adult female illiteracy rate in the country is over $25 \%$ higher than that of males. The over all percentage between both male and female are $23 \%$ for males and $46.9 \%$ for females. (ILO,2007).(Dawn, Saturday, Oct. 6, 2007). 
- Pakistan Economic survey 2006-7 states that due to the government policies the Gender Parity Index (GPI) for Gross Enrolment Rate (GRE) at the primary level increased from 0.73 in 2001-2 to 0.85 in 2005-6 and for Net Enrolment Rate (NER) at the primary level it increased from 0.82 to 0.85 during the same period. (Pakistan Economic Survey 2007).(Dawn, Saturday, Oct.6, 2007).

\section{Health}

- Dec. 1, makes the world HIV/AIDS day, a day that reminds us of how vulnerable we are as a society to HIV/AIDS. According to UNAIDS estimates, there are now 39.5 million people living with HIV worldwide, including 2.3 million children. In Pakistan there are estimated 80,000 to 100,000 HIV cases, out of which only 4,000 are registered. Although numbers in Pakistan are not alarming as those of neighboring countries like India, and China, at least not yet, the stakes are still extremely high. (Dawn, Saturday, Dec.1,2007).

\section{Honor killing}

- Atleast 1,481 persons, including 367 women and 21 minor girls, were murdered during 2007 in various parts of Sindh. 6 people are being killed daily on an average in Sindh of 287 people murdered on the pretext of Karo-Kari, 183 were women. (Aurat Foundation Report 2007).(Dawn, Monday, Nov. 12, 2007).

- According to a report by the UN on violence against women, honor killing takes place in Pakistan, Turkey, Jordan, Syria, Egypt, Lebanon, Iran, Yemen, Morocco, and other Mediterranean and Gulf countries. It also occurs in countries like Germany, France, and the UK within immigrant communities. It is not only prevalent in Islamic countries or communities. Brazil is cited as a case in point, where killing is justified to define the honor of the husband in the case of a wife's adultery.(Dawn, Sunday, Nov. 25, 2007).

\section{Domestic Violence}

- Domestic violence is a phenomenon not new to any society. Number of burn case reported by women in Pakistan is particularly disturbing which shows no sign of decreasing. Data collected by Madadgar Helpline for children and women states that 162 women were set on fire in Sindh in 2001, 75 in 2002, 123 in 2003, 168 in 200, more than 100 each in 2005 and 2006, and 82 in 2007 from January to August. However the over all data collected from overall Pakistan from Jan. to Aug. 2007 of women burn victims goes way above 1,779.(Madadgar Helpline).( Dawn, Monday, Oct. 22, 2007). 
- Human Rights Commission of Pakistan report for 2006 claims that 113 women in Punjab had been burnt out of which only seven were unmarried, the report does not include the data of women who are supposedly burnt because of their own mistakes.(HRCP,2006).(Dawn, Monday, Oct. 22, 2007) 